\title{
Considering seasonal fluctuations in equalizing time series by means of artificial neural networks for predicting development of USA and People's Republic of China trade balance
}

\author{
Jaromír Vrbka ${ }^{1}$, Petr Šuleř ${ }^{1}$, Veronika Machová ${ }^{1}$, Jakub Horák ${ }^{1}$ \\ ${ }^{1}$ School of Valuation and Expertness, Institute of Technology and Business in České \\ Budějovice
}

\begin{abstract}
Balance of payments is an accounting identity of each country. The ability to make a qualified and accurate prediction of trade balance of huge world economies such as the USA and the People's Republic of China economies can have influence on the world's economy. An enormous expansion and advancement of artificial intelligence offers a possibility to measure and predict also this indicator. The aim of the contribution is to propose a methodology for taking into account the seasonal fluctuations in equalizing time series by means of artificial neural networks on the example of the USA and People's Republic of China trade balance. For the analysis, the trade balance data of the two countries from the period between 1985 and 2018 are used. Regression by means of neural structures is carried out in two alternatives, where the second calculation takes into account the monthly seasonality of the time series. The result indicates that the additional variable in the form of the month in which the value was measured enables more order and accuracy. The other experimental calculation indicates that especially the fourth and the fifth retained neural networks are able to capture the whole course of the trade balance. They are thus able to identify and maintain local fluctuations of the time series, that is, to maintain its seasonal course. An interesting fact is also that in the case of the first alternative, the most successful networks were only the radial basis function neural networks, while in the second alternative those were only the multilayer perceptron networks.
\end{abstract}

Keywords: time series; artificial neural networks; trade balance; seasonal fluctuations; additional categorical variable; prediction. 


\section{Introduction}

Global market has improved the living standards of people all over the world. The global market offers individual services and products produced in a certain state, but are sold and used in a different state. As a result, a term referring to goods produced "in the world" emerged (Lawrence, 2018). After the converting all exported and imported goods to monetary value and determining the proportion between the value of imported and exported goods, it is possible to speak about balance of payments for a concrete state. The trade balance of payments is an accounting identity of each state (Müller-Plantenberg, 2010). Moreover, this contribution will deal with the USA and the People's Republic of China (PRC) trade balance of payments.

Zhang et al. (2017) says that the overall USA balance of payments has been negative since 1975. However, in 2009, the USA became a net exporter as regards forestry products. This could have been due to the reduction of forestry products in the USA between 2007 and 2010. Luppold et al. (2014) focused on analyzing the amount of exported and imported hardwood, which, according to his study, has increased significantly in the last years. According to Zhang et al. (2017), only a change in target exporting and importing countries was observed. Increase in products purchasing power was also due to depreciation of American dollar. These facts, together with the Lacey's Act on the ban of illegal trade with animals, affected the balance of payments in several branches. According to Chen (2014), the USA is the world's largest consumer of goods. In recent years, the USA imports more technologically advanced products (Wang, 2018). Ali (2016) states, that the USA has a higher return on investment than the other compared states. This fact has been a subject of literature on global imbalance. While since 1990, the USA imported the goods especially from and to Europe, in 2013 the PRC became the most important market (Zhang et al., 2017). Bahmani-Oskooee et al. (2013) focused on the export from the USA to Hong Kong for 143 industrial sectors and import from Hong Kong to the USA for 110 industrial sectors and found differences in export and import between the individual sectors. Standard International Trade Classification (SITC 7) shows a low negative coefficient both for the export and import from the USA. Most probably, these industrial sectors are protected against external competition better than smaller industrial sectors.

Based on the analysis of the PRC import and export data from the period of 1997-2012, the PRC becomes the world's leading purchaser of goods. However, this growth can be gradually limited by lagging behind the technical development. Over time, the PRC became the world and regional second largest purchaser of goods. The current pace of the PRC growth may cause that the USA will lose its leading position. In the case of primary purchased PRC goods, the current price on the global market is set according to the needs of the PRC, which improves its position on the global markets (Chen, 2014). In recent years, the PRC balance of payments has been increasingly destabilizing. Currently, the economic balance is a global problem (Huang et al., 2017). In this context, Murakami et al. (2018) investigated the PRC economic growth impact on Brazil, Chile and Peru and stated that the PRC economic growth impact on these states is minimal (1\%). 
According to the USA government, the trade with the PRC in 2005 showed a deficit of USD 201,6 billion. According to the PRC, this deficit in the same year was USD 114,2 billion. This is 85.4-billion difference, which is not sufficiently explained. Fung et al. (2006) attempted to adjust the calculation of the overall balance by completing this equation by 4 other important import and export data, which had not been included by the governments. After adjustment, the import and export differences between the PRC and USA are still hight - USD 189,7 billion vs. 219,5 billion. These differences are attributed by the authors to the re-export through other destinations, such as Macao, Japan, South Korea, the Philippines, Singapore, or even Taiwan. In 2005, the PRC showed a deficit of nearly USD 80 billion USD. According to Rasheed et al. (2019) the balance of payments deficit in the importing countries can be reduced by reducing the import of luxury goods, encouraging domestic producers to export or lowering the exchange rate.

In theory, it is possible to predict the fluctuations of the balance of payments based on the financial flows. According to Kandil (2009), this theoretical basis cannot be used to identify the trade balance of payments between the individual states. In accordance with the results of her study, financial flows fluctuation in individual states is random, as evidenced by statistical tests. However, such randomness raises concerns about the sustainability of the growing trade deficit and funding sources in many developing countries. Gouvea et al. (2010) used a multi-sectoral approach of Thirlwall's growth model to analyze the balance of payments growth and to create alternative methodology for analyzing the development of export and import elasticity. This alternative methodology enables to capture the impact of structural change reflected in the change of sector composition of international trade, in changing the elasticity of aggregate income.

Since the balance of payments analysis is always based on the data from a time series, for its prediction it is possible to use increasingly popular Kohonen artificial neural networks. Kohonen artificial neural networks are networks with future ties to historic financial data. However, in the economic sector using artificial neural networks is still at its beginning (Fioretti, 2004). The author of the artificial neural networks (Dr. Teuvo Kohonen) originally designed these networks for recognition of speech and its translation into text (Kohonen, 1990). The advantage of the artificial neural networks is their ability to predict a future development on the basis of non-linear relations of training data (KahyaÖzyirmidokuz et al., 2015). Kohonen artificial neural network works on the principle of assigning weight to the individual vectors, where the winning neurons are the neurons with the shorted Euclidean distance. The selected neurons activate all surrounding neurons and assign a higher weight to their vectors (Cai et al., 2008). Vochozka (2018) or Konečný et al. (2010) have already explored the usability of these neural networks in the economic sector. Also Šuleř (2017) points to a high degree of their future use.

The objective of the contribution is to propose a methodology for considering seasonal fluctuations when equalizing the time series by means of artificial neural networks on the example of the United States of America and the PRC trade balance. 


\section{Methods and Data}

The data for analysis are available at the World Bank websites, etc. For the analysis, the information about the trade balance between the USA and the PRC. It will refer to the difference between the total export and import between the two countries from the USA's point of view. The time interval for which the data is available is the monthly balance starting from January 1985 and ending in August 2018, that is, 404 input data in total. The unit is billions of US dollars.

The data descriptive characteristics are given in Table 1.

Table 1.

\begin{tabular}{lcc}
\hline \multicolumn{1}{c}{ Samples } & Month (Input variable) & Balance (Output (target) \\
\hline Minimum (Training) & 31048.00 & -38569.6 \\
Maximum (Training) & 43313.00 & 155.5 \\
Average (Training) & 37316.95 & -12814.0 \\
Standard deviation (Training) & 3549.13 & 11337.5 \\
Minimum (Testing) & 31138.00 & -34989.5 \\
Maximum (Testing) & 42948.00 & -17.7 \\
Average (Testing) & 36651.48 & -11114.8 \\
Standard deviation (Testing) & 3758.45 & 12253.4 \\
Minimum (Validation) & 31199.00 & -34518.0 \\
Maximum (Validation) & 42979.00 & -67.8 \\
Average (Validation) & 37060.87 & -11574.6 \\
Standard deviation (Validation) & & 11435.8 \\
Minimum (Overall) & 5186.49 & -12377.6 \\
Maximum (Overall) & 31048.00 & 11419.3 \\
Average (Overall) & 43313.00 & 37180.08 \\
\hline Standard deviation (Overall) & 3554.16 & \\
\hline
\end{tabular}

Source: Own processing.

An interesting phenomenon is the development of the trade balance over time. Figure 1 shows graphs of chosen statistic characteristics, including the input data histogram. 
Figure 1. Basic statistic characteristics

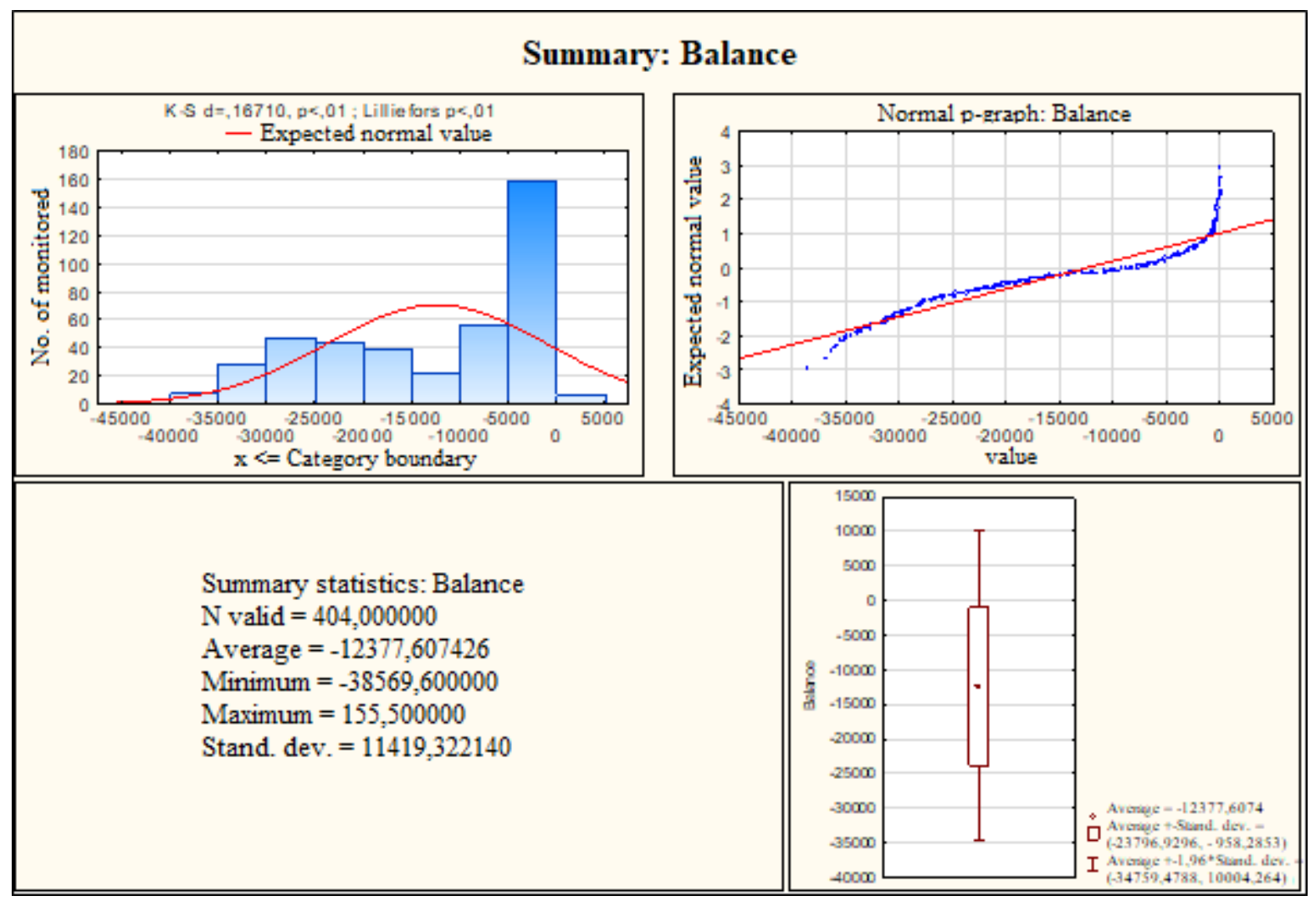

Source: Own processing.

What is interesting is the fact that the histogram does not correspond with the standard division. For data processing, DELL's Statistica software, version 12 will be used. Regression using neural structures will be carried out. Multi-layer perceptron networks and radial basis function networks will be generated. Two sets of artificial neural networks will be generated:

1. An independent variable will be time. A dependent variable will be the USA and the PRC trade balance.

2. A continuous dependent variable will be time. Seasonal fluctuations will be represented by categorical variable - a month in which the value was measured. We will thus work with a possible monthly seasonality of the time series. The dependent variable will be the USA and the PRC trade balance.

We will then work analogically with the data sets. The time series will be divided into three data sets - training, testing and validation data set. The first group will contain $70 \%$ of the input data. Based on the training data set, neural structures will be generated. The remaining two data sets will contain $15 \%$ of the input information each. Both data sets will be used for verification of the generated neural structure or model reliability. The delay of the time series will be $1.10,000$ neural networks will be generated, out of which 5 with the best characteristics will be retained. The hidden layer will contain at least to 
neurons (50 at most). In the case of the radial basis neural structure, the hidden layer will contain at least 21 neurons (30 at most). For the multi-layer perceptron network will consider the following distribution functions in the hidden and output layers: Linear, Logistic, Atanh, Exponential, Sinus.

Other settings will remain default (according to the ANS tool - automated neural networks). Finally, both groups of retained neural networks will be compared.

\section{Results}

\section{Neural structures $A$}

Based on the aforementioned procedure, 10,000 neural networks were generated, out of which 5 with the best parameters were retained. For the overview of the retained networks, see Table 2 .

Table 1. Retained neural networks

\begin{tabular}{|c|c|c|c|c|c|c|c|c|c|}
\hline $\begin{array}{l}\text { Networ } \\
\mathrm{k}\end{array}$ & $\begin{array}{l}\text { Training } \\
\text { performan } \\
\text { ce }\end{array}$ & $\begin{array}{l}\text { Testing } \\
\text { performan } \\
\text { ce }\end{array}$ & $\begin{array}{l}\text { Validation } \\
\text { performan } \\
\text { ce }\end{array}$ & $\begin{array}{l}\text { Trainin } \\
\text { g error }\end{array}$ & $\begin{array}{l}\text { Testing } \\
\text { error }\end{array}$ & $\begin{array}{l}\text { Validatio } \\
\text { n error }\end{array}$ & $\begin{array}{l}\text { Training } \\
\text { algorith } \\
\mathrm{m}\end{array}$ & $\begin{array}{l}\text { Error } \\
\text { function }\end{array}$ & $\begin{array}{l}\text { Activatio Output } \\
\mathrm{n} \quad \text { of activatio } \\
\text { hidden } \mathrm{n} \\
\text { layer function }\end{array}$ \\
\hline $\begin{array}{l}\mathrm{RBF} \\
1-22-1\end{array}$ & 0.976717 & 0.990200 & 0.981291 & $\begin{array}{l}29344 \\
6\end{array}$ & $\begin{array}{l}148632 \\
7\end{array}$ & $\begin{array}{l}230365 \\
2\end{array}$ & RBFT & $\begin{array}{l}\text { Sum.qua } \\
\text { rt. }\end{array}$ & Gaussian Identity \\
\hline $\begin{array}{l}\text { RBF } \\
1-21-1\end{array}$ & 0.980752 & 0.994040 & 0.981226 & $\begin{array}{l}242958 \\
6\end{array}$ & $\begin{array}{l}152887 \\
7\end{array}$ & $\begin{array}{l}230518 \\
7\end{array}$ & RBFT & $\begin{array}{l}\text { Sum.qua } \\
\text { rt. }\end{array}$ & Gaussian Identity \\
\hline $\begin{array}{l}\text { RBF } \\
1-29-1\end{array}$ & 0.980805 & 0.991049 & 0.983911 & $\begin{array}{l}242293 \\
1\end{array}$ & $\begin{array}{l}150638 \\
5\end{array}$ & $\begin{array}{l}194520 \\
4\end{array}$ & RBFT & $\begin{array}{l}\text { Sum.qua } \\
\mathrm{rt}\end{array}$ & Gaussian Identity \\
\hline $\begin{array}{l}\text { RBF } \\
1-25-1\end{array}$ & 0.979270 & 0.991914 & 0.981607 & $\begin{array}{l}261472 \\
8\end{array}$ & $\begin{array}{l}2134330 \\
0\end{array}$ & $\begin{array}{l}240293 \\
4\end{array}$ & RBFT & $\begin{array}{l}\text { Sum.qua } \\
\text { rt. }\end{array}$ & Gaussian Identity \\
\hline $\begin{array}{l}\text { RBF } \\
1-24-1\end{array}$ & 0.979458 & 0.991623 & 0.980938 & $\begin{array}{l}259134 \\
0\end{array}$ & $\begin{array}{l}141348 \\
2\end{array}$ & $\begin{array}{l}235381 \\
2\end{array}$ & RBFT & $\begin{array}{l}\text { Sum.qua } \\
\text { rt. }\end{array}$ & Gaussian Identity \\
\hline
\end{tabular}

\section{Source: Own processing.}

The retained networks are only the radial basis function networks. The hidden layer contains only one variable - time. The neural networks contain 21-29 neurons in the hidden layer. The output layer contains logically only 1 neuron and 1 output variable the USA and PRC trade balance. For all networks, RBFT training algorithm was applied. In addition, all neural networks used the same function to activate the neurons in hidden layer, namely Gaussian curve. Similarly, for the activation of the neurons in the output layer, the same function was used, namely the identity function (for more details, see Table 2).

Training, testing and validation performances are also interesting. In general, we are looking for such a network, whose performance is ideally the same in all data sets (here it should be noted that the data were randomly divided into the data sets). At the same time, the error should be as small as possible. 
The individual data sets performance is given in the form of correlation coefficient. The individual data sets values by specific neural networks are given in Table 3 .

Table 2. Correlation coefficient of individual data sets

\begin{tabular}{llll}
\hline Neural structure & Balance (Training) & Balance (Testing) & Balance (Validation) \\
\hline 1.RBF 1-22-1 & 0.976717 & 0.990200 & 0.981291 \\
2.RBF 1-21-1 & 0.980752 & 0.994040 & 0.981226 \\
3.RBF 1-29-1 & 0.980805 & 0.991049 & 0.983911 \\
4.RBF 1-25-1 & 0.979270 & 0.991914 & 0.981607 \\
5.RBF 1-24-1 & 0.979458 & 0.991623 & 0.980938
\end{tabular}

Source: Own processing.

It results from the table, that the performance of all the retained neural structures is almost identical. The slight differences detected do not affect the performance of the individual networks. The value of all training data sets correlation coefficient ranges between more than 0.97 to more than 0.98 . The value of testing data sets for all neural networks is more than 0.99 . In the case of the validation data sets, the correlation coefficient for all neural networks is above 0.98 . In order to choose the most suitable neural network, a more detailed analysis of the results obtained must be carried out. Table 4 shows the basis statistic characteristics of the individual data sets for all neural structures.

Table 3. Statistics of individual data sets by retained neural structures

\begin{tabular}{|c|c|c|c|c|c|}
\hline Statistics & $\begin{array}{l}1 . \quad \mathrm{RBF} \\
1-22-1\end{array}$ & $\begin{array}{l}2 . \quad \mathrm{RBF} \\
1-21-1\end{array}$ & $\begin{array}{l}3 . \quad \mathrm{RBF} \\
1-29-1\end{array}$ & $\begin{array}{l}\text { 4. RBF } \\
1-25-1\end{array}$ & $\begin{array}{l}5 . \quad \mathrm{RBF} \\
1-24-1\end{array}$ \\
\hline Minimum prediction (Training) & -33729.8 & -32812.1 & -35611.6 & -30887.5 & -32039.2 \\
\hline Maximum prediction (Training) & 385.0 & 202.7 & 465.0 & 312.0 & 312.4 \\
\hline Minimum prediction (Testing) & -33279.1 & -31325.5 & -31741.1 & -30826.9 & -31946.5 \\
\hline Maximum prediction (Testing) & 275.2 & 162.1 & 464.2 & 168.6 & 294.9 \\
\hline Minimum prediction (Validation) & -33365.7 & -31632.1 & -31812.1 & -30843.1 & -31988.5 \\
\hline Maximum prediction (Validation) & 298.4 & 24.6 & 392.5 & 201.5 & 218.5 \\
\hline Minimum residuals (Training) & -9657.5 & -6683.2 & -7327.8 & -7711.6 & -7774.1 \\
\hline Maximum residuals (Training) & 9716.2 & 8571.1 & 8882.7 & 9283.4 & 10189.8 \\
\hline Minimum residuals (Testing) & -5983.8 & -5753.2 & -6109.0 & -5218.5 & -5993.8 \\
\hline Maximum residua (Testing) & 4588.2 & 2638.7 & 4905.4 & 3590.0 & 3531.9 \\
\hline Minimum residuals (Validation) & -6164.3 & -5445.2 & -5767.4 & -4992.1 & -6785.3 \\
\hline Maximum residuals (Validation) & 6573.3 & 8822.7 & 5667.2 & 7733.7 & 7408.2 \\
\hline Minimum standard residua (Training) & -5.6 & -4.3 & -4.7 & -4.8 & -4.8 \\
\hline Maximum standard residuals (Training) & 5.7 & 5.5 & 5.7 & 5.7 & 6.3 \\
\hline
\end{tabular}




\begin{tabular}{|c|c|c|c|c|c|c|c|}
\hline \multicolumn{3}{|c|}{ Minimum standard residuals (Testing) } & -4.9 & -4.7 & -5.0 & -4.5 & -5.0 \\
\hline \multicolumn{3}{|c|}{ Maximum standard residuals (Testing) } & 3.8 & 2.1 & 4.0 & 3.1 & 3.0 \\
\hline $\begin{array}{l}\text { Minimum } \\
\text { (Validation) }\end{array}$ & standard & residuals & -4.1 & -3.6 & -4.1 & -3.2 & \\
\hline $\begin{array}{l}\text { Maximum } \\
\text { (Validation) }\end{array}$ & standard & residuals & 4.3 & 5.8 & 4.1 & 5.0 & 4.8 \\
\hline
\end{tabular}

Source: Own processing.

Ideally, the individual statistics of a neural network are horizontally identical in all data sets (minimum, maximum, residuals, etc.). In the case of equalized time series, the differences are minimal. There are bigger differences in the residuals characteristics. However, it is not possible to determine the retained neural networks with the best results unequivocally. Based on Table 4, it can be the network No. 3. RBF1-29-1.

Figure 2 shows a line graph representing the actual development of the USA and the PRC trade balance and at the same time the predictions development made by means of the individual generated and retained networks.

It follows from the graph that each neural network's prediction of the trade balance development is slightly different. However, what is important is not the similarity of the individual networks' prediction but the similarity (or the degree of consistency) with the actual trade balance development. Even in this respect, it can be stated that all the retained neural networks appear to be interesting at first sight. They follow the gradient of the curve showing the trade balance development and at the same time show the extremes of this curve. 
Figure 2. Line graph of USA and PRC trade balance predicted using neural network comparison with actual trade balance in monitored period

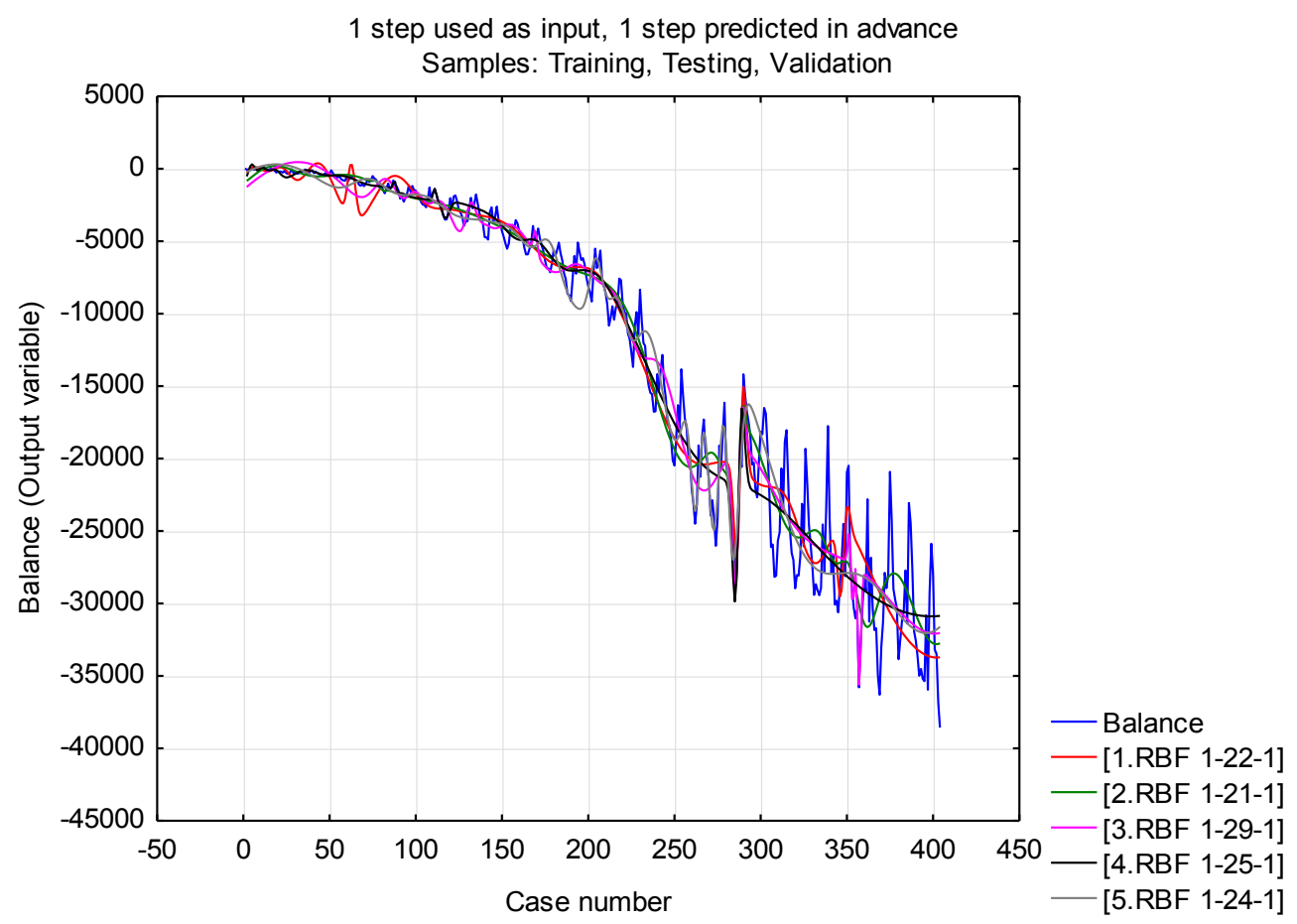

Source: Own processing.

\section{Neural structures $B$}

In accordance with the procedure described above, other 10,000 neural networks were generated, out of which 5 with the best parameters were retained. Table 5 shows the overview of the retained networks.

Table 4. Retained neural networks

\begin{tabular}{|c|c|c|c|c|c|c|c|c|c|c|}
\hline Network & $\begin{array}{l}\text { Training } \\
\text { performance }\end{array}$ & $\begin{array}{l}\text { Testing } \\
\text { performance }\end{array}$ & $\begin{array}{l}\text { Validation } \\
\text { performance }\end{array}$ & $\begin{array}{l}\text { Training } \\
\text { error }\end{array}$ & $\begin{array}{l}\text { Testing } \\
\text { error }\end{array}$ & $\begin{array}{l}\text { Validation } \\
\text { error }\end{array}$ & $\begin{array}{l}\text { Training } \\
\text { algorithm }\end{array}$ & $\begin{array}{l}\text { Error } \\
\text { function }\end{array}$ & $\begin{array}{l}\text { Activation } \\
\text { of hidde } \\
\text { layer }\end{array}$ & $\begin{array}{l}\text { Output } \\
\text { activation } \\
\text { function }\end{array}$ \\
\hline $\begin{array}{l}\text { MLP } \\
13-23-1\end{array}$ & 0.993132 & 0.994897 & 0.992814 & 879530.4 & 880802.0 & 950952.0 & BFGS 147 & Sum.quart. & Logistic & Logistic \\
\hline $\begin{array}{l}\text { MLP } \\
13-4-1\end{array}$ & 0.992884 & 0.994211 & 0.992703 & 914069.2 & 941123.8 & 983968.1 & BFGS 99 & Sum.quart. & Tanh & Logistic \\
\hline $\begin{array}{l}\text { MLP } \\
13-6-1\end{array}$ & 0.993308 & 0.995170 & 0.992898 & 849468.7 & 866824.0 & 950204.7 & BFGS 161 & Sum.quart. & Logistic & Identity \\
\hline $\begin{array}{l}\text { MLP } \\
13-13-1\end{array}$ & 0.993615 & 0.994443 & 0.992741 & 815152.2 & 924102.1 & 967511.0 & BFGS 66 & Sum.quart. & Tanh & Logistic \\
\hline $\begin{array}{l}\text { MLP } \\
13-8-1\end{array}$ & 0.994173 & 0.994883 & 0.993739 & 740142.4 & 872853.2 & 865006.4 & BFGS 94 & Sum.quart.. & Tanh & Logistic \\
\hline
\end{tabular}

Note: BFGS (= Quasi-Newton algorithm).

Source: Own processing 
The networks are multi-layer perceptron networks only. The hidden layer contains two variables - time (continuous variable) and the month in which the measurements were carried out (categorical variable). Time is represented by one neuron in the input layer, while the relevant month by 12 neurons. The neural networks in the hidden layer contain between $4-23$ neurons. The output layer logically contains only one neuron and one output variable, i.e. the USA and PRC trade balance. The Quasi-Newton training algorithm was used for all networks, but for each network, a different alternative was used. The neural networks used logistics and hyperbolic tangent functions for the activation of the neurons in the hidden layer. Similarly, two functions are used for the activation of the neurons in the output layer - identity and logistic functions (for more details, see Table 5). As an error function, all the retained neural structures used the sum of the least squares.

Table 6 shows the values of the individual data sets by the concrete neural networks.

Table 5. Correlation coefficient of individual data sets

\begin{tabular}{llll}
\hline Neural structure & Balance (Training) & Balance (Testing) & Balance (Validation) \\
\hline 1.MLP 13-23-1 & 0.993132 & 0.994897 & 0.992814 \\
2.MLP 13-4-1 & 0.992884 & 0.994211 & 0.992703 \\
3.MLP 13-6-1 & 0.993308 & 0.995170 & 0.992898 \\
4.MLP 13-13-1 & 0.993615 & 0.994443 & 0.992741 \\
5.MLP 13-8-1 & 0.994173 & 0.994883 & 0.993739
\end{tabular}

Source: Own processing

It follows from the table that the performance of all the retained neural structures is nearly identical. The slight differences detected do not have any influence on the individual network's performance. The correlation coefficient value of all training data sets ranges between the values higher than 0.992 and above 0.994 . The testing data sets correlation coefficient achieves the value above 0.994 for all neural networks, while the value of the validation data sets correlation coefficient is above 0.992 . In order to choose the most suitable neural structure, a more detailed analysis of the results obtained must be carried out. Table 7 shows the basic statistic characteristics of the individual data sets for all neural structures. 
Table 6. Statistics of individual data sets by retained neural networks

\begin{tabular}{|c|c|c|c|c|c|}
\hline Statistics & $\begin{array}{l}\text { 1.MLP } \\
13-23-1\end{array}$ & $\begin{array}{l}2 . M L P \\
13-4-1\end{array}$ & $\begin{array}{l}3 . M L P \\
13-6-1\end{array}$ & $\begin{array}{l}\text { 4.MLP } \\
13-13-1\end{array}$ & $\begin{array}{l}5 . M L P \\
13-8-1\end{array}$ \\
\hline Minimum prediction (Training) & -35608.8 & -34320.2 & -35612.9 & -35883.9 & -36063.3 \\
\hline Maximum prediction (Training) & 155.5 & 153.2 & 843.7 & 135.8 & 152.2 \\
\hline Minimum prediction (Testing) & -34787.1 & -33761.5 & -34802.6 & -35030.4 & -35370.1 \\
\hline Maximum prediction (Testing) & 155.5 & -488.0 & 1019.6 & 127.4 & 146.9 \\
\hline Minimum prediction (Validation) & -35600.9 & -34020.4 & -35380.9 & -35884.5 & -36220.2 \\
\hline Maximum prediction (Validation) & 155.2 & -484.4 & -28.3 & 96.8 & 97.6 \\
\hline Minimum residuals (Training) & -8864.3 & -7831.5 & -8582.0 & -8458.7 & -8676.8 \\
\hline Maximum residuals (Training) & 4727.0 & 4753.2 & 4531.0 & 5026.8 & 4597.4 \\
\hline Minimum residuals (Testing) & -2208.9 & -3086.0 & -1950.0 & -2274.1 & -1976.0 \\
\hline Maximum residua (Testing) & 5194.4 & 6059.4 & 5326.8 & 5487.6 & 5404.7 \\
\hline Minimum residuals (Validation) & -2593.3 & -2683.1 & -2708.5 & -2110.6 & -2298.8 \\
\hline Maximum residuals (Validation) & 4776.6 & 5348.1 & 4812.7 & 4475.3 & 4736.8 \\
\hline Minimum standard residua (Training) & -9.5 & -8.2 & -9.3 & -9.4 & -10.1 \\
\hline $\begin{array}{lll}\text { Maximum } & \text { standard } & \text { residuals } \\
\text { (Training) } & & \end{array}$ & 5.0 & 5.0 & 4.9 & 5.6 & 5.3 \\
\hline Minimum standard residuals (Testing) & -2.4 & -3.2 & -2.1 & -2.4 & -2.1 \\
\hline Maximum standard residuals (Testing) & 5.5 & 6.2 & 5.7 & 5.7 & 5.8 \\
\hline $\begin{array}{lll}\text { Minimum } & \text { standard } & \text { residuals } \\
\text { (Validation) } & & \end{array}$ & -2.7 & -2.7 & -2.8 & -2.1 & -2.5 \\
\hline $\begin{array}{lll}\text { Maximum } & \text { standard } & \text { residuals } \\
\text { (Validation) } & & \end{array}$ & 4.9 & 5.4 & 4.9 & 4.5 & 5.1 \\
\hline
\end{tabular}

Source: Own processing

The individual statistics of the neural networks are horizontally identical in ideal case (minimum, maximum, residuals, etc.). In the case of equalized time series, the differences are minimal. Minimal differences also appear at the residual's characteristics. In spite of this, we are not able to determine unequivocally the retained neural network with the most suitable results. According to Table 4, it may be the network No. 4 MLP 13-13-1.

Figure 3 shows a line graph representing the actual development of the USA and the PRC trade balance as well as the development of the predictions made by means of the individual generated and retained networks.

The graph clearly indicates that all neural networks' predictions of the trade balance development in the individual intervals are slightly different. However, what is important is not the similarity of the individual networks' predictions, but the similarity (or the 
degree of consistency) with the actual trade balance development. Even in this respect, it can be stated that all the retained neural networks appear to be interesting at first sight. All of them predict not only the basic trade balance development trend but are also able to predict local minimum and maximum.

Figure 1. Line graph - development of USA and PRC trade balance predicted by means of neural networks. Comparison with actual trade balance in the monitored period

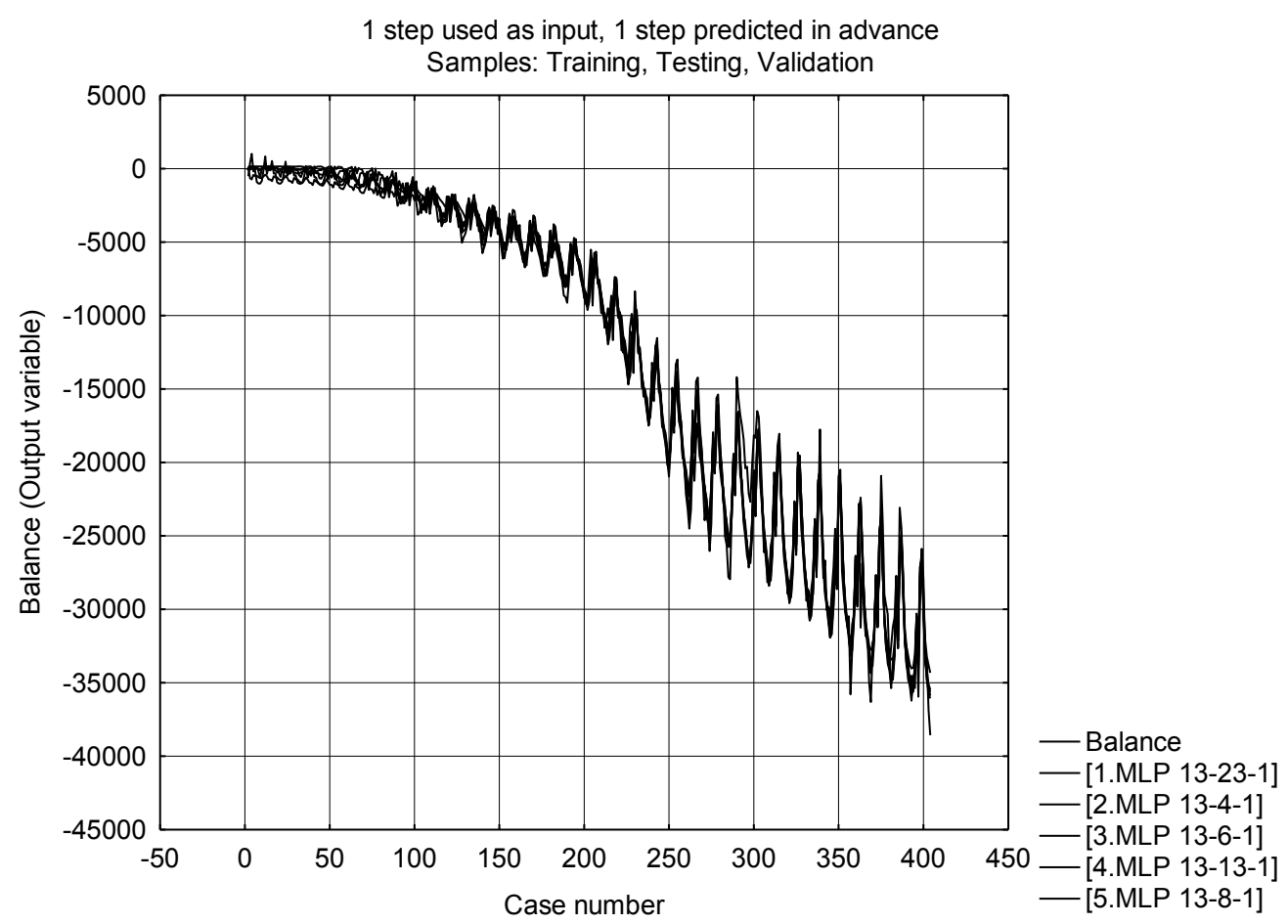

Source: Own processing

The figure indicates that there are two neural networks particularly applicable: $4^{\text {th }}$ MLP 13-13-1 and $5^{\text {th }}$ MLP 13-8-1.

\section{Comparison of $A$ and $B$ results}

All generated and retained artificial neural networks were capable of equalizing the time series - the USA and the PRC trade balance. It results from the comparison of correlation coefficients (see Tables 3 and 6) that the B alternative's performance (i.e. the retained MLP networks) is higher (when the additional categorical variable is included). This is reflected also when evaluating the basis predictions statistics (equalized time series) in Tables 4 and 7. The retained MLP networks, or their equalized time series, show smaller differences in the training, testing and validation data sets compared to the RBF networks (without additional variable). This can be clearly seen in Figures 2 and 3. At a glance, it is obvious that only the MLP networks, alternative $B$, are able to capture the time series in accordance with its actual course. At the beginning of the time series it seems that the 
results are similar to the A alternative (at least in the case of the 1.MLP $12-23-1$, 2.MLP $13-4-1$ and 3.MLP $13-1$ networks). Only the networks 4.MLP $13-13-1$ and 5.MLP $13-8-1$ are able to capture the entire course of the USA and PRC trade balance. However, since the $150^{\text {th }}$ observation, all five multi-layer perceptron networks are able to identify and follow the local fluctuations of the time series, that is, to preserve its seasonal course.

\section{Conclusion}

The objective of the contribution was to propose a methodology for considering seasonal fluctuations when equalizing the time series by means of artificial neural networks on the example of the United States of America and the PRC trade balance.

In general, each prediction is given by a certain probability degree of its fulfilment. To predict the development trend of any variable means to estimate its future development on the basis of the data from the previous periods. Although we are able to include most of the factors influencing the target variable in the model, there is always certain simplification of the reality; we thus work with a certain degree of probability that the scenario predicted will come true.

It can be stated that due to great simplification of the reality it is not possible to predict extraordinary situations and their possible influence on the USA and the PRC trade balance (maybe only in the short term). Prediction in the order of days would be ideal; however, currently it is not possible to obtain data for such a short-term prediction.

In this contribution, the results of applying the same tool with a different initial instructions. Although before the experiment it seemed unnecessary to use categorical variable in order to consider the seasonal fluctuations of the trade balance, the opposite proved to be true. Using an additional variable in the form of the month in which the measurements had been carried out resulted in better order and greater accuracy of the equalized time series.

The trade balance of both states can be identified based on the statistical, causal and intuitive methods. This contribution dealt with comparing the statistical methods. However, we only got a possible framework of the variable development. It is important to work with the information about a possible development of the economic, political or legal environment. If we are able to predict its development, we will be able to incorporate it in the monitored trade balance. However, what is of the same importance is the personality of the evaluator - an economist who corrects the price set by means of statistical methods and specified on the basis of the causal links in line with his / her experience and knowledge. Nevertheless, in this case it is only possible to test the prediction using the $B$ alternative, which enables a high degree of accuracy. Very interesting results are shown by the networks 4. MLP $13-13-1$ and 5. MLP $13-81$. The objective of the contribution was achieved. 
A very interesting fact is that in the case of the A alternative, the most suitable structures were only the radial basis neural networks. On the contrary, in the case of the B alternative, those were only the multilayer perceptron neural networks. It would certainly be an interesting experiment, if we generated only one type of neural networks for a given situation, always different from the results obtained (that is, the MLP networks for the A alternative, RBF networks for the B alternative).

\section{References}

ALI, M., 2016. Global imbalances and asymmetric returns to US foreign assets: fitting the missing pieces of the US balance of payments puzzle. International Review of Applied Economics [online]. ISSN 14653486. doi:10.1080/02692171.2015.1085002

BAHMANI-OSKOOEE, M., HEGERTY S. W. and XU, J. 2013. Exchange-rate volatility and USHong Kong industry trade: Is there evidence of a "third country" effect? Applied Economics [online]. ISSN 00036846. doi:10.1080/00036846.2012.654918

CAI, Y. and GUO, Q., 2008. Point set generalization based on the Kohonen net. Geo-Spatial Information Science [online]. ISSN 10095020. doi:10.1007/s11806-008-0091-y

FIORETTI, G., 2004. The investment acceleration principle revisited by means of a neural network. Neural Computing and Applications [online]. ISSN 09410643. z: doi:10.1007/s00521-004-0398-z

FUNG, K. C., Lawrence J. L AU and XIONG Y., 2006. Adjusted estimates of United StatesChina bilateral trade balances: An update. Pacific Economic Review [online]. ISSN 1361374X. doi:10.1111/j.1468-0106.2006.00317.x

GOUVEA, Raphael Rocha a Gilberto Tadeu LIMA, 2010. Structural change, balance-ofpayments constraint, and economic growth: Evidence from the multisectoral Thirlwall's law. Journal of Post Keynesian Economics [online]. ISSN 01603477. Dostupné z: doi:10.2753/PKE0160-3477330109

HUANG, S. and ZHANG, J., 2017. Analysis of the Main Causes of the Imbalance of International Payments and Risk Prediction. In: [online]. doi:10.2991/icefs-17.2017.59

CHEN, I. T., 2014. Balance of payments and power: Assessing China's global and regional interdependence relationship. International Relations of the Asia-Pacific [online]. ISSN 14704838. doi:10.1093/irap/lcu001

KANDIL, M., 2009. On the relation between financial flows and the trade balance in developing countries. Journal of International Trade and Economic Development [online]. ISSN 09638199. doi:10.1080/09638190902986520

KOHONEN, T., 1990. The Self-Organizing Map. Proceedings of the IEEE [online]. ISSN 15582256. doi:10.1109/5.58325 
KONEČNÝ, V., O. TRENZ and E. SVOBODOVÁ, 2018. Classification of companies with the assistance of self-learning neural networks. Agricultural Economics (Zemědělská ekonomika) [online]. ISSN 0139570X. doi:10.17221/60/2009-agricecon

LAWRENCE, R. Z., 2018. Can the Trading System Survive US-China Trade Friction? China and World Economy [online]. ISSN 1749124X. doi:10.1111/cwe.12256

LUPPOLD, W. G. and. BUMGARDNER, M. S., 2014. Changes in the International Trade Balance of U.S. Hardwood products from 1990 to 2013. BioResources [online]. ISSN 19302126. doi:10.15376/biores.9.4.7086-7098

MÜLLER-PLANTENBERG, Nikolas A., 2010. Balance of payments accounting and exchange rate dynamics. International Review of Economics and Finance. ISSN 10590560. Dostupné z: doi:10.1016/j.iref.2009.02.010

MURAKAMI, Y. and HERNÁNDEZ R. A, 2018. The impacts of china on economic growth: Evidence for brazil, chile, and peru. Journal of Post Keynesian Economics [online]. ISSN 15577821. doi:10.1080/01603477.2016.1136565

OZYIRMIDOKUZ, E. K., UYAR K. and OZYIRMIDOKUZ M. H., 2015. A Data Mining Based Approach to a Firm's Marketing Channel. Procedia Economics and Finance [online]. ISSN 22125671. doi:10.1016/s2212-5671(15)00975-2

RASHEED, R., MEO, M. S., AWAN R. U. and AHMED F., 2019. The impact of tourism on deficit in balance of payments of Pakistan: an application of bounds testing approach to cointegration. Asia Pacific Journal of Tourism Research [online]. ISSN 17416507. doi:10.1080/10941665.2018.1564345

ŠULĚ̌, P., 2017. Using Kohonen neural networks to identify the bankruptcy of enterprises: Case study based on construction companies in South Bohemian region. 5th International Conference Innovation Management, Entrepreneurship and Sustainability 985-995.

VOCHOZKA, M., 2018. Analysis of enterprises operating in the construction industry based on Kohonen networks. 12th International Days of Statistics and Economics 18741883.

WANG, Y., 2018. Effects of exchange rate and income on the US bilateral trade with China under Chinese managed floating exchange rate system. Journal of Chinese Economic and Foreign Trade Studies [online]. ISSN 1754-4408. doi:10.1108/jcefts-042018-0009

ZHANG, D., LIN Y. and PRESTEMON J. P., 2017. From Deficit to Surplus: An Econometric Analysis of US Trade Balance in Forest Products. Forest Science [online]. ISSN 0015-749X. doi:10.5849/fs-2016-018 


\section{Contact address of the author(s):}

Ing. Jaromír Vrbka, MBA, PhD., School of Valuation and Expertness, Institute of Technology and Businessin České Budějovice, Okružní 517/10, České Budějovice 37001, Czech Republic, email: vrbka@mail.vstecb.cz

Mgr. Petr Šuleř, PhD., School of Valuation and Expertness, Institute of Technology and Businessin České Budějovice, Okružní 517/10, České Budějovice 37001, Czech Republic, email: petr.suler@cez.cz

Ing. Veronika Machová, MBA, School of Valuation and Expertness, Institute of Technology and Businessin České Budějovice, Okružní 517/10, České Budějovice 37001, Czech Republic, email: machova@mail.vstecb.cz

Ing. Jakub Horák, School of Valuation and Expertness, Institute of Technology and Businessin České Budějovice, Okružní 517/10, České Budějovice 37001, Czech Republic, email: horak@mail.vstecb.cz 